\title{
The Helm Wind of Crossfell
}

\section{Introduction}

Crossfell is the highest point along the 268-mile route of the Pennine Way, at 893 metres (Figure 1). The climate of the North Pennines is temperate, with a small area classified as subarctic (Manley, 1936). The hills generally receive more precipitation, stronger winds, and colder temperatures than the surrounding areas. They are also home to the Helm, England's only named wind.

\section{Figure 1}

The Helm is a true 'local' wind, being a product of the particular landscape and climatic conditions found at Cross Fell. It is an example of a 'Foehn' type wind (Brinkmann, 1971) and is caused when there is high pressure over or to the north of Scotland and low pressure over or to the south of England, resulting in relatively strong East to North Easterly winds across the Pennines. It occurs when the horizontal component of airflow is virtually perpendicular to the hills, restricting wind to a North Easterly direction, and when a stable layer of air lies about $600 \mathrm{~m}$ above the summit of the range. A temperature inversion above the Pennines helps to force the air through a relatively narrow gap, and wind speed is intensified as it descends the $600 \mathrm{~m}$ of the Cross Fell escarpment to the Eden Valley. Three or four miles from the foot of the Fell, a signature cigar shaped, rotor cloud (the 'Helm Bar') often forms and remains stationary. Cold wind blows down the Fell until it reaches the 'Bar' and suddenly ceases, while clear sky usually separates the two cloud banks (Uttley, 1998). The name itself most probably comes from the Anglo-Saxon, signifying a helmet or covering for the head, and is a reference to the distinctive bank of cloud that covers the summit whilst the wind blows (the 'Helm Cloud'). The gap between the Helm Cloud and the Helm Bar represents the descending air and will vary according to temperature and pressure conditions.

\section{Early Accounts of the Wind}

Investigations of the British Newspaper Archive have uncovered accounts of the Helm Wind dating back to 1794 (Table 1). These references afford insight into the frequency, duration and impacts of Helm events, and, when combined with other sources, document how understanding of this local wind changed during a period of over 200 years.

The earliest reference to the Helm, dated 15 November 1794, suggested that its very presence could threaten human health. The report charts penal action against a Vicar in the county of Cumberland, for non-residence:

"...this gentleman was greatly afflicted with a spasmodic asthma; that his house stood on one of the highest mountains in England, where the wind, called the helm-wind, was excessively sharp and piercing...When he was at the communion-table, his lungs were so much affected by the helm-wind that he fell down. He was unable to reside in that place, and therefore he removed from thence by the advice of his physician. It was admitted ...that if he had continued to reside there, suffocation was unavoidable." ${ }^{1}$

\footnotetext{
${ }^{1}$ WEDNESDAY'S POST, The Ipswich Journal, 15 November 1794.
} 
A more complex picture over the Helm's relative healthiness emerged in the published descriptions of the region. It was argued that "in the vicinity of these mountains the air is generally very clear and healthy, owing, perhaps, to the violent Helm-winds in the months of December, January, February, March, and April: but the inhabitants of the countries immediately influenced by that wind, are more subject to rheumatic complaints than those at a greater distance" (Britton et al., 1802: 69-69). Similarly, a reference to the Helm Wind from 1854 noted, "It is a curious fact that fever still lingers about Ousby, and is ever breaking out with fatal effect. A more salubrious situation would be difficult to meet with, as the atmosphere is regularly purified by the helm wind." ${ }^{2}$

Early descriptions of the physical impacts of the Helm Wind detail "corn stacks, the stone walls which divide the inclosures, the roofs of the houses, the stunted trees that grow in exposed situation, in short everything that is exposed... its impetuous force." ${ }^{33}$ Damage to vegetation, and the disruption of agricultural activities was frequently reported. In 1857 "it took the entire roof from a man's house" in Dufton "carrying it to a distance... of fifty yards into a field, and leaving it as perfect as if found on the top of the building. ${ }^{\prime 4}$ In 1866 the Helm was blamed for the collapse of the only remaining tower of Haresceugh Castle, whereas tents at a village fair fell victim in 1868, facilitating the actions of an opportunist thief. ${ }^{5}$ The strength of the wind led to falling trees, horses and carts being overturned and horses also dying of fright, terrified by the strong wind. ${ }^{6}$ Fears for losses of sheep were reported in 1844 and 1886 and an account from 1857 suggested that, "It [the Helm] sometimes blows the sheep about like so many pieces of wool." ${ }^{7}$ Disruptions to the mail service were reported in 1828 and 1844, and transport difficulties were commonplace, particularly when the Helm was accompanied by snow $(1841,1844) .{ }^{8}$ In 1859 , a human tragedy unfolded:

"At Dudmire, a large tree was likely to be blown down upon the roof of the house of a farmer, and fearing the house might be seriously injured by the fall thereof, a man named John Robinson was employed to cut it down. Suddenly a gust of wind broke the remaining hold of the tree, which fell upon poor Robinson, who has since died from the injuries he received, leaving a wife and five children." ${ }^{\prime 9}$

\section{Table 1}

Data generated using the British Newspaper Archive (www.britishnewspaperarchive.co.uk).

\begin{tabular}{|c|c|c|c|}
\hline Year & $\mathbf{N}^{\circ}$ of events & Month(s) & Comment \\
\hline 1794 & 1 & ? & Affecting health of resident Vicar. \\
\hline 1807 & 1 & May & $\begin{array}{l}\text { Unabated force of wind for two days, accompanied by a } \\
\text { sudden transition from intense heat to extreme cold. }\end{array}$ \\
\hline \multicolumn{4}{|c|}{2 DIED, Kendal Mercury, 29 April 1854.} \\
\hline \multicolumn{4}{|c|}{${ }^{3}$ THE HELM WIND (Newcastle Magazine, November), Bath Chronicle and Weekly Gazette, 22 November 1827.} \\
\hline \multicolumn{4}{|c|}{${ }^{4}$ KENDAL LITERARY AND SCIENTIFIC INSTITUTE, THE HELM WIND, Westmorland Gazette, 25 April 1857.} \\
\hline \multicolumn{4}{|c|}{${ }^{5}$ FALL OF HARESCEUGH CASTLE, Carlisle Journal, 13 April 1866; ROBBERY OF $£ 30$ AT BROUGH HILL FAIR, Kendal Mercury, } \\
\hline \multicolumn{4}{|c|}{${ }^{6}$ THE HELM WIND, Westmorland Gazette, 28 May 1831; THE WEATHER, Kendal Mercury, 17 February 1855.} \\
\hline \multicolumn{4}{|c|}{${ }^{7}$ SNOW STORM IN THE NORTH, Morning Post, 26 March 1844; THE SNOWSTORM, DISTRICT REPORTS, Carlisle Patriot, 5} \\
\hline \multicolumn{4}{|c|}{ March 1886; THE HELM WIND, Westmorland Gazette, 25 April 1857.} \\
\hline \multicolumn{4}{|c|}{${ }^{8}$ MAIL COACH, Westmorland Gazette, 19 January 1828; DREADFUL SNOW-STORM IN THE NORTH, Morning Post, 19 March } \\
\hline
\end{tabular}




\begin{tabular}{|c|c|c|c|}
\hline 1815 & 1 & December & $\begin{array}{l}\text { Postman from Keswick to Alston perished in snow. Two } \\
\text { countrymen travelling in same area - one blown from his } \\
\text { horse as if struck with the rapidity of lightning }\end{array}$ \\
\hline 1821 & 1 & Winter & Indirect reference from 1827 \\
\hline 1828 & 1 & January & Terrible storm, mail upset near Appleby. \\
\hline 1831 & 1 & May & $\begin{array}{l}\text { Carrying peats high into the air, terrifying a horse which } \\
\text { set off at a gallop, rushing into a rock and killed on the } \\
\text { spot. }\end{array}$ \\
\hline 1841 & 1 & January/February & Blowing for a fortnight; no serious damage. \\
\hline 1843 & 1 & May/June & Blowing for 15 days. \\
\hline 1844 & 2 & $\begin{array}{l}\text { March } \\
\text { November }\end{array}$ & $\begin{array}{l}\text { Raging with unusual violence, mail disrupted by wind and } \\
\text { snow. } \\
\text { Blew with more violence than it has been known to do for } \\
\text { many years past. }\end{array}$ \\
\hline 1845 & 1 & September & Helm wind from the east. \\
\hline 1849 & 1 & April & Blowing for three weeks \\
\hline 1850 & 1 & January & $\begin{array}{l}\text { Helm wind roaring and blowing with considerable } \\
\text { violence. }\end{array}$ \\
\hline 1853 & 1 & May & Helm wind blew most boisterously. \\
\hline 1854 & 1 & March & Blowing most furiously for a fortnight. \\
\hline 1855 & 2 & $\begin{array}{l}\text { February } \\
\text { November }\end{array}$ & $\begin{array}{l}\text { Never known to be stronger, horse and cart blown over } \\
\text { and the horse killed. } \\
\text { Blowing most monstrously. }\end{array}$ \\
\hline 1856 & 4 & $\begin{array}{l}\text { April } \\
\text { July } \\
\text { September } \\
\text { December }\end{array}$ & $\begin{array}{l}\text { Blowing everyday for a week. } \\
\text { Like a hurricane stopping all mowing. } \\
\text { Grain shaken from heads of corn. } \\
\text { Christmas Day. }\end{array}$ \\
\hline 1857 & 2 & $\begin{array}{l}\text { March } \\
\text { April }\end{array}$ & $\begin{array}{l}\text { Wind of great fury. } \\
\text { Magnificent clouds and great noise. }\end{array}$ \\
\hline 1858 & 1 & March & Helm wind blowing. \\
\hline 1859 & 1 & May & $\begin{array}{l}\text { Helm wind blowing boisterously and piercingly cold, } \\
\text { houses partially unroofed, trees broken, fences and stone } \\
\text { walls damaged and a laden cart blown over injuring the } \\
\text { driver seriously. Death of man employed to cut down } \\
\text { damaged tree. }\end{array}$ \\
\hline 1866 & 1 & March & Only remaining tower of Haresceugh Castle blown down. \\
\hline 1867 & 1 & March & $\begin{array}{l}\text { Strong helm and snowstorm, farmers prevented from } \\
\text { going to market. }\end{array}$ \\
\hline 1868 & 1 & October & $\begin{array}{l}\text { Strong helm wind, lifting tents at fair, facilitating } \\
\text { opportunist theft. }\end{array}$ \\
\hline 1879 & 1 & Spring & Helm wind blowing almost without intermission. \\
\hline 1880 & 1 & July & Terrible helm doing considerable damage. \\
\hline 1885 & $41 ?$ & & As reported in press by RMetS investigation. \\
\hline 1886 & $\begin{array}{l}1 \\
63 ?\end{array}$ & March & $\begin{array}{l}\text { Helm wind and snowstorm together, roads blocked. } \\
\text { As reported in press by RMetS investigation. }\end{array}$ \\
\hline 1887 & $19 ?$ & & As reported in press by RMetS investigation. \\
\hline 1888 & 1 & April & $\begin{array}{l}\text { Indirect reference from } 1895 \text { - not for many years had } \\
\text { there been so severe and prolonged a prevalence of the } \\
\text { Helm wind. It began on Friday and lasted until Wednesday } \\
\text { night. }\end{array}$ \\
\hline 1890 & 2 & April & Boisterous helm winds preventing angling in the Upper \\
\hline
\end{tabular}




\begin{tabular}{|c|c|c|c|}
\hline & & August & $\begin{array}{l}\text { Eden. } \\
\text { Helm raging with much violence, cartloads of hay blown } \\
\text { away. }\end{array}$ \\
\hline 1891 & 3 & $\begin{array}{l}\text { January } \\
\text { June } \\
\text { October }\end{array}$ & $\begin{array}{l}\text { Helm wind sweeping in from snow covered hills. } \\
\text { Cold helm prevailing made erection of tent very difficult. } \\
\text { Harvest failure; hurricanes of the helm wind uprooted } \\
\text { trees and hurled grain still standing out in the fields. }\end{array}$ \\
\hline 1895 & 1 & December & $\begin{array}{l}\text { Prevailing on Christmas Eve with much violence in } \\
\text { Cumberland and Westmorland. }\end{array}$ \\
\hline 1899 & 1 & August & Reference to the appearance of the Helm Bar. \\
\hline 1909 & 1 & March & $\begin{array}{l}\text { Helm Wind blowing on Cumberland for some days, } \\
\text { accompanied by snowstorms. }\end{array}$ \\
\hline 1913 & 1 & October & Reference to a Helm Wind brewing during a ramble. \\
\hline 1935 & 1 & July & $\begin{array}{l}\text { Tufts of hay seen floating along } 2000 \text { feet up over } \\
\text { Windermere. Reference to previous events where the } \\
\text { spray from the lakes has been lifted several hundred feet } \\
\text { high by the wind. }\end{array}$ \\
\hline TOTAL & $\begin{array}{l}42(+123 \\
\text { reported by } \\
\text { RMetS) in } 141 \\
\text { years. }\end{array}$ & $\begin{array}{l}\text { Occurring in all } \\
\text { months of the year. }\end{array}$ & \\
\hline
\end{tabular}

\section{Emerging Scientific Interest in the Helm Wind}

As was the case elsewhere in Britain, clergymen played an important role in documenting weather events throughout the nineteenth century (Jankovic, 2001). Reverend William Walton provided remarks on the Helm Wind to the Royal Society in 1830 in which he explained, "It is accompanied by a loud noise, like the roaring of distant thunder: and is carefully avoided by travellers in that district [Cumberland], as being fraught with considerable danger" (459). Eight years later, Reverend J Watson of Cumrew (c.8 miles from Crossfell) read a paper on the subject of the Helm Wind of Crossfell at the meeting of the British Association for the Advancement of Science. Watson described the unusual cloud formation, and irregularity of the Helm Wind, as well as its sound, "it has been compared to the noise made by the sea in a violent storm, or that of a large cotton mill when all the machinery is going" (1839:34).

Published accounts of the Helm Wind appear with greater frequency in historical and geographical guides for the counties of Cumberland and Westmorland from the 1820s. Sopwith's Account of the Mining Districts of Alston Moor, Weardale and Teesdale in Cumberland and Durham (1833) was the first to include instrumental measurements of temperature, emphasising the temperature differential (up to $14^{\circ} \mathrm{F}$ ) between the top and bottom of Crossfell. Thomas Barnes, Fellow of the Royal Society of Edinburgh and Physician Extraordinary to the Dispensary, similarly provided an account for Whellan's The History and Topography of the Counties of Cumberland and Westmoreland (1860), in which he demonstrated an understanding of the effect of temperature on the atmospheric uptake of water vapour (Uttley, 1998). Such county studies show how early meteorologists' work "developed local knowledge that could contribute to a wider picture through comparison with other parts of the country" (Sloan, 2011: 336).

Once blowing, the general belief throughout the nineteenth century was that the Helm Wind could continue, unabated, for "three hours, three days or three weeks" (Manley, 1945: 212). Newspaper 
accounts report the Helm blowing for 15 days in June $1843,{ }^{10}$ up to 3 weeks in $1863,{ }^{11}$ and in 1879 "during the spring months the helm wind has blown almost without intermission." 12

Newspaper reports and regional guides thus outlined a phenomenon that was considered to be at once fascinating and devastating. Limited understanding of the Helm served to attract national attention and fostered a series of investigations.

\section{National Interest}

\section{i) The Royal Meteorological Society (RMetS)}

A paper entitled "The Helm Wind" was read by Reverend Joseph Brunskill at the June $18^{\text {th }} 1884$ meeting of the RMetS. Brunskill drew on personal experience to describe the distinctive noise which was thought to give warning of the imminent winds. Following the interest generated by Brunskill's paper, the RMetS appointed a Committee, "consisting of the President, Secretaries, Prof. Archibald, Mr C.Harding and Mr. Whipple" (RMetS, 1885a: 76) to collect information on the subject.

The Committee considered it desirable, "that a circular letter should be inserted in the Penrith newspapers...inviting the contribution of records of past dates of Helm winds, and simple observations of various kinds in future" (RMetS, 1885b: 226). From the material received, 93 instances of the Helm were identified in the period 1871-1884. The highest frequency was found in March and April, but Helm events were reported in all months of the year but July. Using the daily weather charts, the prevailing conditions of 'Helm days' were found to be easterly wind over the entire country. The received accounts highlighted an amateur interest in studying the Helm, "Mr Grierson had from time to time, prior to 1865 , made experiments with small fire balloons and rockets during some of the Helm winds, but unfortunately his numerous memoranda and diaries containing detailed accounts have been lost" (RMetS, 1885b: 231).

The Committee requested that William Marriott (Assistant Secretary of the RMetS), visit the Helm Wind district. With T.G. Benn (Fellow of RMetS and resident of Penrith who volunteered to act as local superintendent for the Society in the investigation) he travelled around the area, making "numerous inquiries at each of the villages as to the appearance of the Helm Cloud, the Helm Bar, the peculiarities of the wind, and its effects, \&c" (Marriott, 1886: 1). The pair were presented with multiple accounts of Helm Wind-induced havoc, though they found that "At very few places could we get precise information as to what the persons had actually seen or experienced". This led them to conclude "that past accounts were of little value, and that observations must be made on a systematic plan in order to obtain reliable data to throw light on the cause of the Helm Wind" (2).

On descending Crossfell on the evening of August $18^{\text {th }} 1885$, the visiting party were "so fortunate as to witness a slight Helm" (3). Their subsequent account highlighted the local nature of the wind and its effects, each experiencing a sudden transition in air temperature and wind speed as they walked away from the Helm (Figure 2). Eight members of the Penrith and District Literary and Scientific Society subsequently agreed to take observations during Helm events and it was suggested that "a

\footnotetext{
${ }^{10}$ Newcastle Journal, 10 June 1843.

11 The Border Magazine, November, 1863, William P. Nimmo: Edinburgh, reproduced in the Carlisle Journal, 13 November 1863.

${ }^{12}$ THE LAMBING SEASON ON THE BORDER HILL FARMS, Newcastle Courant, 23 May 1879.
} 
meteorological station should be established at Penrith" (7). Comments by Mr Symons (founder of the British Rainfall Organisation, then honorary secretary of the RMetS) indicated that radical management proposals had been forwarded including the suggestion that "that pipes should be laid up the side of Cross Fell, and when the Helm Cloud was forming quantities of steam should be let off at the top of the Fell by means of these pipes, and so cause the accumulated vapour to disperse" (8).

\section{Figure 2}

Reproduced with kind permission of the National Meteorological Archive. Published in Marriott, 1886:2.

Marriott again presented on the Helm Wind in 1889 when 23 reporters had sent in observations of five Helms occurring between November 1885 and April 1888. The Athenaeum (reporting on the findings of the RMetS inquiry) revealed, "the observations that had been made in the district during the past three or four years showed it [the Helm] was not such a rare occurrence as it was popularly supposed to be, having been observed on 41 occasions in 1885, 63 in 1886, and 19 in 1887."13 The apparently greater prevalence of the phenomenon was perhaps a function of more detailed observation during the investigation or mistaken classification of winds/storms as Helm events. Following the years of the enquiry the Helm was reported less than annually in the newspapers (Table 1).

\section{ii) The work of Gordon Manley}

The Helm attracted the interest of Gordon Manley, who started collecting meteorological data in the Pennines at Moor House in 1932. Following a research award from the Leverhulme Trust in association with an investigation of the 'Helm Wind' of Cumberland and Westmorland, Manley was able to establish a weather recording station close to the summit of Great Dun Fell in the autumn of 1937 (Figure 3).

His station was located in a small wooden hut, $8 \mathrm{ft} . \times 6 \mathrm{ft}$. $x 6 \mathrm{ft}$. erected in a small hollow, a result of past mining operations, chosen so as to ensure that the hut would not blow over, and, "... on the score of ease of access, remoteness and freedom from disturbance by passers-by, and the use which might be made of the writer's older station at Moor House" (Manley, 1945: 200). The hut was placed at the highest point of the escarpment, and where, according to the available evidence, the Helm was most frequent. The hut was equipped with two thermographs, thermometers, a barograph, portable cup anemometer, as well as tools for cooking and clearing snow (Figure 3 ).

\section{Figure 3}

Manley's skis can be seen to the right of the hut whilst the Lake District is visible in the background. ${ }^{14}$ Reproduced with kind permission of Durham University.

During the first year of observations at Great Dun Fell, Manley found occurrences of the 'helm wind' were tantalizingly few (Manley, 1945). ${ }^{15}$ As well as observing and photographing the Helm and its manifestations (see Figure 4), Manley kept meteorological observations for a period of three years

\footnotetext{
${ }^{13}$ Reproduced in: THE HELM WIND, Manchester Times, 18 October 1895.

${ }^{14}$ Durham University Archives, MAN 8/139.

${ }^{15}$ Letter from Armstrong to Manley, $7^{\text {th }}$ November 1940., Gordon Manley Papers (university of Cambridge), Box 2/1.
} 
(1937-1939), including a continuous record of temperature. This was the first series of mountain observations to become available in England and remains the longest unbroken mountain record in the UK. Manley himself made around 100 visits to the hut, generally driving over the Pennines to and from Durham (Manley, 1942: 152). As was the case throughout his career, Manley regularly reported his findings through the mass media as well as in academic journals. In a radio broadcast from the Northern programme from Newcastle, recorded on Thursday $16^{\text {th }}$ February 1939, 7:50pm, Manley explained:

There are many places in the world which are known on account of their characteristic local winds. ...We have, however, a single example in Britain of a more violent local phenomenon, the "Helm Wind" of Cumberland and Westmorland [...]

To walk up the fellside against it is an unforgettable experience, and, while I don't object to wind, I don't recommend going up in a "helm" for pleasure. One stoops against it with everything buttoned up as tight as it can be, and slogs wearily up the hill with this steady roaring torrent of air pressing against one, sometimes at fifty or sixty miles per hour, even on a "fine day". It is very tiring, and if there is snow about it causes severe drifting. Further, east winds being what they are, it is bitterly cold. On the morning of the First of May, on the summit, it blew a gale from North-East with a temperature of only twenty-nine degrees at my hut. ${ }^{16}$

\section{Figure 4}

Photograph taken by Manley and then made into a lantern slide he used in teaching. ${ }^{17}$ Reproduced with kind permission of Durham University.

From direct observation and analysis of his tabulated data relating to temperature, wind speed and atmospheric pressure, as well as comparison with synoptic charts and data from other stations, Manley found that for a Helm to occur, the general direction of the surface wind is between $E$. and N.N.E., the strength of the wind at the summit greater than force 4 , and at Tynemouth no less than force 3, suggesting that the speed of 15 m.p.h. may represent a critical value. The presence of the Helm cloud lying on or slightly above the crest of the range was judged to be essential for the distinctive strong wind to blow.

Manley acknowledged that whilst "local intensifications" of wind of similar origin could be found elsewhere in Britain, "the exceptional fall of the Crossfell escarpment cannot, however, be matched elsewhere in these islands. The combined result of topography and freedom from obstacles is, that a surface wind of strength similar to that which normally prevails in the free air is felt inland over a narrow belt of country; and this development is sufficiently frequent and well-defined to have been given its local name" (Manley, 1945: 214).

\section{Conclusion}

This paper charts how different individuals, social groups and organisations have attempted to observe, measure, understand and explain the complexities of the Helm Wind over a 200-year period, and reveals a long history of fascination with the phenomenon. Ways of knowing the Helm, however, have emerged as much through experience of its impacts, as through the data generated

\footnotetext{
${ }^{16}$ Gordon Manley Papers, Box 2/4.

${ }^{17}$ Durham University Archives, MAN 8/154.
} 
by meteorological instruments. The Helm Wind undoubtedly continues to hold a special place in the popular geographical imagination of the region (Uttley, 1998), and the Crossfell area has continued to be a focus for meteorological investigation more generally. ${ }^{18}$ Historical accounts in newspapers and county guides, however, remain a little explored yet rich source of information about the Helm wind and the general meteorological characteristics of this region that complement the reports of organised investigations and allow insight into this unique phenomenon.

\section{References}

Barnes T. 1860. On the cause of the Helm Wind. In: Whellan W. 1860. The History and Topography of the Counties of Cumberland and Westmoreland. Whellan and Co: Pontefract.

Brinkmann WAR. 1971. What is a foehn? Weather. 26(6): 230-240.

Britton J, Brayley EW, Brewer JN, et al. 1813. The Beauties of England and Wales, Or, Delineations, Topographical, Historical, and Descriptive, of Each County. Volume 14. Thomas Maiden.

Brunskill J. 1884. 'The Helm Wind,' Proceedings of Meetings, June $18^{\text {th }}$ 1884. Q. J.R. Meteorol. Soc., 10: 267-275.

Hutchinson W. 1794-7. The History of the County of Cumberland: and some places adjacent, from the earliest accounts to the present time. Printed by F. Jollie; and sold by B. Law and Son, W. Clark, and T. Taylor, London.

Jankovic V. 2001. Reading the Skies: A Cultural History of English Weather, 1650-1820. University of Chicago Press: Chicago.

Manley G. 1936. The climate of the northern Pennines: The coldest part of England. Q. J.R. Meteorol. Soc., 62(263): 103-115.

Manley G. 1942. Meteorological observations on Dun Fell, a mountain station in northern England. Q. J.R. Meteorol. Soc., 68: 151-166.

Manley G. 1945. The helm wind of Cross Fell 1937-1938. Q. J.R. Meteorol. Soc., 71: 197-215.

Marriott W. 1886. The Helm Wind of August 19 ${ }^{\text {th }}, 1885$. Q. J.R. Meteorol. Soc., 12(57): 1-10.

Marriott W. 1889. Report on the helm wind inquiry. Q. J.R. Meteorol. Soc., 15(70): 103-118.

Pedgley DE. 2001. A helm wind near Dun Fell. Weather, 56(9): 287-289.

Royal Meteorological Society. 1885a. Report of the Council for the year 1884. Q. J.R. Meteorol. Soc., 11(54): 73-104.

\footnotetext{
${ }^{18}$ See http://www.ecn.ac.uk/ [Accessed January 2013]. The site has a number of automatic weather stations that continue to help us explore the characteristics of the Helm Wind (see Pedgley, 2001).
} 
Royal Meteorological Society. 1885b. Report of committee on the occurrences of the Helm Wind of Cross Fell, Cumberland, from 1871 to 1884. Q. J.R. Meteorol. Soc., 11(55): 226-238.

Sloan E. 2011. Meteorologist's profile: Hayman Rooke (1723-1806). Weather. 66(12): 335-336.

Sopwith T. 1833. An Account of the Mining Districts of Alston Moor, Weardale and Teesdale in Cumberland and Durham. W Davison: Alnwick.

Uttley D. 1998. The Anatomy of the Helm Wind: The Scourge of the Cumbrian East Fellside. Bookcase: Cumbria.

Walton W. 1830. A few remarks on the Helm Wind. Abstracts of the Papers Printed in the Philosophical Transactions of the Royal Society of London, 3: 459-460.

Watson J. 1839. On the Helm Wind of Cross Fell. Report of the Eighth Meeting of the British Association for the Advancement of Science held at Newcastle in August 1838, Mathematics and Physics section: 33-34. John Murray: London. 